\title{
ANALISIS PERKEMBANGAN KEMAMPUAN KEUANGAN DAERAH DALAM MENDUKUNG PELAKSANAAN OTONOMI DAERAH PADA DINAS PENDAPATAN DAERAH KOTA TIDORE
}

\author{
Umilhair Alting $^{1}$, Winston Pontoh ${ }^{2}$, I Gede Suwetja $^{3}$ \\ ${ }^{1,2,3}$ Akuntansi, Fakultas Ekonomi dan Bisnis, Universitas Sam Ratulangi, Jl. Kampus Bahu, Manado, 95115, \\ Indonesia \\ E-mail : Umhilmikha@gmail.com
}

\begin{abstract}
Fiscal decentralization is one the major component of the decentralization implementation of regional autonomy. As the new beginning in regional development and the people in managing the resources or all of the potential to the prosperity and the progress of region. Financial aspect is one of the basic criteria to find out the real capability regional government in managing their autonomy system (household system) the capability of regional government in managing their financial can be seen in APBD which describes the capability of local government in financing the activities of development task and equity in each region. The purpose of this research is to determine the financial capability of Tidore in regional autonomy especially in 2013-2017 judging by ratio of independency, decentralization fiscal degree, growth ratio. This research used observation, interview and documentation to collect the data. The data was analyzed using qualitative and quantitative data with described analysis. The result showed that the independence ratio of Tidore has been able to improve its financial capability. The degree of decentralization is still highly dependent on the central government, although it has been increasing year by year. Growth rate fluctuated this indicates the local government of Tidore is not too concerned with regional development and community welfare.
\end{abstract}

Keywords: regional autonomy, ratio of independency, The degree of decentralization ratio, Growth ratio.

\section{PENDAHULUAN}

Pemerintah merupakan salah satu bentuk organisasi non-profit yang yang tujuannya meningkatkan pelayanan kepada masyarakat umum yang dapat berupa meningkatkan keamanan, meningkatkan mutu pendidikan, mutu kesehatan dan lain-lain. Akan tetapi sebagaimana bentuk kelembagaan lainnya pemerintah juga memiliki aspek sebagai lembaga ekonomi. Pemerintah melakukan berbagai bentuk pengeluaran guna membiayai kegiatan yang akan dilakukan dan disisi lain juga harus melakukan berbagai upaya untuk memperoleh penghasilan guna membiayai kegiatan tersebut.

Dalam ekonomi pemerintah membutuhkan jasa atau tenaga akuntansi untuk pengawasan dan mengetahui hasil keuangan yang akan digunakan untak pengambilan keputusan. Peran pemerintah daerah dalam menggali dan mengembangkan berbagai potensi daerah sebagai sumber penerimaan daerah akan sangat menentukan keberhasilan pelaksanaan tugas pemerintah, pembangunan, dan pelayanan masyarakat di daerah (Halim, 2004: 22).

Dengan Peraturan Pemerintah Republik Indonesia Nomor 58 Tahun 2005 tentang Pengelolaan Keuangan Daerah bahwa untuk melaksanakan Pasal 182 dan Pasal 194 UndangUndang Nomor 32 Tahun 2004 tentang Pemerintahan Daerah. Dengan ditetapkan Permendagri Nomor 13 tahun 2006, maka akan terjadi perluasan wewenang pemerintah daerah, Permendagri ini memberikan peluang bagi daerah untuk menggali potensi lokal dan meningkatkan kinerja keuangannya dalam rangka mewujudkan kemandirian daerah. Peran 
pemerintah daerah dalam menggali dan mengembangkan berbagai potensi daerah sebagai sumber penerimaan daerah akan sangat menentukan keberhasilan pelaksanaan tugas pemerintah, pembangunan, dan pelayanan masyarakat di daerah (Halim, 2004: 22).

Otonomi daerah merupakan suatu langka awal menuju pembangunan ekonomi nasional yang lebih berdaya tumbuh tinggi dengan memberikan kehidupan yang lebih baik bagi masyarakat didaerah. Asas yang menjadi prinsip dasar otonomi adalah otonomi luas, nyata dan bertanggungjawab. Prinsip ini memperhatikan aspek demokrasi, partisipasi, adil dan merata dengan tetap memperhatikan potensi dan keragaman daerah. Berdasarkan asas tersebut, diharapkan otonomi daerah mampu mempercepat terwujudnya kesehjatraan masyarakat daerah. Dengan peraturan tersebut pada dasarnya pemerintahan menetapkan prinsip money follow function/ uang yang mengikuti fungsi.

Dalam hal ini sumber daya manusia yang berperan sebagai user/pengguna juga merupakan pilar penyangga utama sekaligus penggerak roda organisasi dalam usaha mewujudkan visi misi serta tujuan dari organisasi tersebut. Menurut Yosefrinaldi (2013), sumber daya manusia adalah kemampuan sumber daya manusia untuk melaksanakan tugas dan tanggungjawab yang diberikan kepadanya dengan bekal pendidikan, pelatihan, dan pengalaman yang cukup memadai.

\section{TINJAUAN PUSTAKA}

\subsection{Otonomi Daerah}

Otonomi daerah merupakan suatu langka awal menuju pembangunan ekonomi nasional yang lebih berdaya tumbuh tinggi dengan memberikan kehidupan yang lebih baik bagi masyarakat didaerah. Autonom yang berarti mengatur sendiri, atau memerintah sendiri, atau dalam arti luas adalah hak untuk mengatur dan mengurus rumah tangga daerah sendiri (Adisubrata, 2003).

Menurut Adisubrata (2003), istilah otonomi mempunyai makna kebebasan atas kemandirian tetapi bukan kemerdekaan, artinya kebebasan yang terbatas, kebebasan yang harus dipertanggungjawabkan kepada pemerintah yang lebih tinggi (pemerintah pusat). Jadi secara umum otonomi daerah itu mencakup tiga pengertian:

a. Hak untuk mengatur dan mengurus rumah tangga sendiri.

b. Wewenang untuk mengatur daerah sendiri.

c. Kewajiban untuk mengatur rumah tangga sendiri.

\subsection{Keungan Daerah}

Keuang daerah adalah semua hak dan kewajiban daerah dalam rangka menyelenggarakan pemerintah daerah yang didalamnya termasuk segala bentuk kekayaan lain yang berhubungan dengan hak dan kewajiban daerah tersebut dalam kerangka APBD. sepanjang sebelum dimiliki atau dikuasai oleh negara atau daerah yang lebih tinggi serta pihak-pihak lain sesuai ketentuan atau peraturan. Keuangan Daerah dapat juga diartikan sebagai semua hak dan kewajiban yang dapat dinilai dengan uang, juga dengan segala satuan, baik yang berupa uang maupun barang, yang dapat dijadikan kekayaan daerah sepanjang belum di miliki/dikuasai oleh negara atau daerah yang lebih tinggi serta pihak-pihak lain sesuai ketentuan/peraturan perundangan yang berlaku. (Mamesa, 1995 dalam Abdul Halim, 2007).

\subsection{Pendapatan Daerah}

Pendapatan daerah adalah semua hak daerah yang diakui sebagai penambahan nilai kekayaan bersih dalam periode anggaran tertentu (UU.No 32 Tahun 2004 tentang pemerintahan daerah), pendapatan daerah berasal dari penerimaan dana perimbangan pusat dan daerah, juga berasal dari daerah itu sendiri yaitu pendaptan asli daerah serta lain-lain yang termasuk pendapatan daerah yang sah. 


\subsection{Anggaran pendapatan belanja daerah (APBD)}

Guna menunjukkan alokasi sumber daya manusia, material, dan sumber daya lainnya secara sistematis dan akuntabel, diperlukan suatu rencana keuangan yang handal dan terwujud dalam suatu penganggaran. Terkait dengan rencana manajemen, sistem penganggaran berfungsi sebagai suatu metode penganggaran bagi manajemen untuk mengaitkan setiap biaya yang dituangkan dalam kegiatan-kegiatan dengan manfaat yang dihasilkan dimana manfaat tersebut dideskripsikan melalui seperangkat sasaran dan dituangkan dalam target kinerja pada setiap unit kerja. Untuk mengidentifikasi keterkaitan biaya dengan manfaat serta keterkaitan antara nilai uang dan hasil di tingkat pemerintahan daerah, pemerintah daerah menuangkan penganggaran tersebut dalam suatu rencana keuangan yang dikenal dengan Anggaran Pendapatan dan Belanja Daerah (APBD).

\subsection{Analisis Rasio Keuangan Berdasarkan Anggaran Pendapatan Belanja Daerah (APBD)}

Ciri utama yang menunjukkan suatu daerah otonom mampu berotonomi adalah terletak pada kemampuan keuangan daerah untuk membiayai penyelenggaraan pemerintahan daerahnya dengan tingkat ketergantungan kepada pemerintah pusat yang mempunyai proporsi semakin kecil. Oleh karena itu, diharapkan PAD dapat menjadi bagian terbesar dalam memobilisasi dana penyelenggaraan pemerintahan daerah. Untuk melihat kemampuan daerah dalam menjalankan otonomi daerah, salah satunya dapat diukur melalui kinerja keuangan daerah. Abdul Halim (2012) Menyatakan bahwa salah satu alat untuk menganalisis kinerja pemerintah daerah dalam mengelola keuangan daerahnya adalah dengan melakukan analisis keuangan terhadap Anggaran Pendapatan dan belanja Daerah ( APBD) yang telah ditetapkan dan dilaksanakannya.

\subsubsection{Rasio Kemandirian Keuangan Daerah}

Keberhasilan kemampuan keuangan daerah dalam mendukung pelaksanaan otonomi daerah, salah satunya dilihat dari kemandirian keuangan daerah tersebut. suatu daerah yang sudah mandiri dalam aspek keuangan diharapkan bisa melaksanakan pembangunan dan pelayanan kepada masyarakat tanpa diharapkan transfer dana dari pemerintah pusat. Rasio kemandirian ditunjukkan oleh besarnya pendapatan asli daerah dibandingkan dibandingkan dengan pendapatan daerah yang berasal dari sumber lain (pihak ekstern) antara lain : Bagi hasil pajak, Dana Alokasi Umum dan Dana Alokasi Khusus, (Widodo, 2001 : 262).

\subsubsection{Rasio Pertumbuhan ( Growh Ratio)}

Menurut ihyaul (2009), rasio pertumbuhan (grown ratio) mengukur seberapa besar kemampuan pemerintah daerah dalam mempertahankan dan meningkatkan keberhasilan yang telah dicapai dari satu periode ke periode berikutnya.

\subsubsection{Derajad Desentralisasi Fiskal}

Menurut Ihyaul Ulum (2009), derajat desentralisasi fiskal antara pemerintah pusat dan daerah pada umumnya ditujukkan oleh variabel-variabel Pendapatan Asli Daerah (PAD) terhadap Total Penerimaan Daerah (TPD), Rasio Bagi Hasil pajak untuk daerah (BHPBP) terhadap Total Penerimaan daerah (TPD).

\section{METODE PENELITIAN}

\subsection{Jenis Data}

Pada penelitian ini digunakan jenis penelitian deskriptif kualitatif dengan dengan metode studi kasus pada objek penelitian. Deskriptif kualitatif merupakan salah satu dari jenis penelitian yang termasuk dalam jenis penelitian kualitaif. Adapun tujuan dari penelitian ini adalah untuk mengungkapkan kejadian atau fakta, ekadaan, fenomena, variabel, dan keadaan yang terjadi saat penelitian berlangsung dengan menyungguhkan apa yang sebenarnya terjadi. 


\subsection{Tempat dan Waktu Penelitian}

Lokasi penelitian yang dilaksanakan di kota Tidore. Dengan alamat jalan. A. Malawat No. 194-Tidore 97812 Maluku Utara, 2018.

\subsection{Prosedur Penelitian}

Prosedur penelitian yang ditempuh oleh penulis adalah dengan menjalankan tahaptahap penelitian, dimana semuanya dimulai dengan mengevaluasi objek penelitian untuk menemukan persoalan atau masalah yang akan diangkat, kemudian penulis merumuskan masalah tersebut dan dilanjutkan dengan membuat rencana penelitian tentang persoalan tersebut, mengumpulkan data dan informasi yang relevan, mengolah data tersebut, menyajikan data serta melakukan analsis tentang data tersebut dan akhirnya menuangkan dalam bentuk laporan penelitian.

\subsection{Metode Analisis Data}

Metode analisis data meliputi antara lain:

1) Wawancara

2) Observasi

3) Dokumentasi

\subsection{Sumber Data}

Untuk menganalisis masalah dalam penilitian ini maka data yang digunakan adalah:

1) Data primer adalah data yang diambil langsung dari perusahaan tempat dilakukannya penelitian melalui observasi dan wawancara, dengan terjun langsung ke lapangan dan pengamatan OTS (On The Spot).

2) Data sekunder adalah data yang diperoleh dari hasil dokumentasi baik itu dari studi kepustakaan, yang diperoleh dari beberapa sumber dengan mengambil data statistik yang sudah ada serta dokumen-dokumen lain yang terkait dan diperlukan

\section{HASIL ANALISIS DAN PEMBAHASAN}

4.1 Hasil

\subsubsection{Perhitungan Rasio Kemandirian Pada Dinas Pendapatan Kota Tidore}

Rasio Kemandirian Keuangan Daerah pada Dinas Pendapatan Daerah Kota Tidore menunjukkan tingkat kemampuan suatu daerah dalam membiayai sendiri kegiatan pemerintah, pembangunan dan pelayanan kepada masyarakat yang telah membayar pajak dan retribusi sebagai sumber pendapatan yang diperlukan daerah. Rasio Kemandirian ditunjukkan oleh besarnya pendapatan asli daerah dibandingkan dengan pendapatan daerah yang berasal dari sumber lain (pihak ekstern) antara lain: bagi hasil pajak, bagi hasil bukan pajak sumber alam, dana alokasi umum dan alokasi khusus, dana darurat dan pinjaman. Rasio ini dihitung mengggunakan rumus sebagai berikut:

$$
\text { Rasio Kemandirian }=\frac{\text { Pendapatan Asli Daerah (PAD) }}{\text { Sumber Pendapatan dari Pihak Ekstern }} \times 100
$$


Table 4.1 Perhitungan Rasio Kemandirian pada Dinas Pendapatan Daerah Kota Tidore Tahun Anggaran 2013-2017

\begin{tabular}{|c|c|c|c|c|c|c|}
\hline & $\begin{array}{c}\text { Sumber } \\
\text { Pendapatan dari } \\
\text { Pihak Ekstern }\end{array}$ & 2013 & 2014 & 2015 & 2016 & 2017 \\
\hline 1 & Bagi Hasil Pajak & $21,416,756,463$ & $31,672,891,278.00$ & $26,164,908,993.00$ & $15,552,011,526.00$ & $7,911,307,773.00$ \\
\hline 2 & $\begin{array}{l}\text { Dana Alokasi } \\
\text { Umum }\end{array}$ & $443,177,446,000$ & $497,417,022,000.00$ & $514,588,698,000.00$ & $554,976,092,000.00$ & $545,226,947,000.00$ \\
\hline 3 & $\begin{array}{c}\text { Dana Alokasi } \\
\text { Khusus }\end{array}$ & $55,218,880,000$ & $49,139,160,000.00$ & $58,915,240,000.00$ & $113,932,645,670.00$ & $104,246,995,700.00$ \\
\hline \multicolumn{2}{|c|}{$\begin{array}{c}\text { Total Sumber } \\
\text { Pendapatan dari Pihak } \\
\text { Ekstern }\end{array}$} & $519,813,084,476$ & $578,229,073,278.00$ & $\begin{array}{l}599,668,846,993.00 \\
\end{array}$ & $684,460,751,212.00$ & $657,385,252,490.00$ \\
\hline \multicolumn{2}{|c|}{ Pendapatan Asli Daerah } & $16,351,196,253$ & $27,672,173,877$ & $33,695,174,505.00$ & $38,730,845,221.00$ & $51,238,072,570$ \\
\hline \multicolumn{2}{|r|}{ Rasio Kemandirian } & $31,45 \%$ & $4,78 \%$ & $5,61 \%$ & $5,65 \%$ & $7,79 \%$ \\
\hline \multicolumn{2}{|r|}{ Pola Hubungan } & Instruktif & Instruktif & Instruktif & Instruktif & Instruktif \\
\hline
\end{tabular}

Sumber : Dinas Pendapatan Daerah Kota Tidore (Data Olahan)

Kemandirian keuangan daerah Pada Dinas Pendapatan Daerah Kota Tidore menunjukkan kemampuan pemerintah daerah dalam membiayai sendiri kegiatan pemerintahan, pembangunan dan pelayanan kepada masyarakat yang telah membayar pajak dan retribusi sebagai sumber pendapatan yang diperlukan daerah. Kemandirian daerah Kota Tidore dalam berotonomi dapat diketahui melalui seberapa besar kemampuan sumber daya keuangan daerah tersebut dalam membangun daerahnya sendiri, selain itu pula mampu bersaing secara sehat dengan kota/kabupaten lainnya dalam mencapai cita-cita otonomi yang sesungguhnya. Upaya nyata dalam mengukur tingkat kemandirian Kota Tidore yaitu dengan membandingkan besarnya relaisasi Pendapatan Asli Daerah (PAD) dengan total penerimaan.

Tabel diatas menunjukan bagaimana perhitungan Rasio Kemandirian Kota Tidore dari tahun 2013 sampai dengan tahun 2017 untuk mencari Rasio Kemandirian kita perlu menggunakan Rumus, yaitu pendaptan asli daerah dibagi dengan Total Pendapatan Dari Pihak Ekstern dan dikalikan dengan 100, maka hasilnya akan didapat, seperti yang bisa kita lihat pada tabel diatas, dimana Rasio kemandirian pada tahun 2013 31,45\%, tahun 2014 4,78\%, tahun 2015 5,61\%, tahun 2016 5,65\%, dan pada tahun 2017 7,79\% ini menunjukan pola hubungan Rasio Kemandirian yang ada di Kota Tidore tahun 2013 sampai dengan 2017 adalah instruktif (sangat baik). Hasil tersebut menunjukkan bahwa peranan Pemerintah pusat masih sangat dominan bagi daerah Kota Tidore dan itu dapat dilihat dari besarnya penerimaan yang berasal dari pemerintah pusat atau instansi yang lebih tinggi, dana perimbangan serta dana lain-lain penerimaan yang sah.

\subsubsection{Hasil Perhitungan Rasio Derajat Desentralisasi Fiskal Dinas Pendapatan Daerah Kota Tidore Tahun Anggarann 2013-2017}

Derajat desentralisasi dihitung berdasarkan perbandingan antara jumlah PAD dengan total pendapatan daerah. Merupakan cara yang digunakan untuk menilai kemampuan keuangan daerah artinya dengan menghitung derajat desentralisasi maka dapat diketahui atau diukur seberapa besar kemampuan keuangan daerah pemerintah kota Tidore ini dalam mengolah PAD. Rasio ini dihitung mengggunakan rumus sebagai berikut.

Derajat Desentralisasi Fiskal $=\frac{\text { Pendapatan Asli Daerah }(\mathrm{PAD})}{\text { Total Penerimaan Daerah }} \times 100$


Table 4.2 Perhitungan Rasio Derajat Desentralisasi Fiskal Pada Dinas Pendapatan Daerah Kota Tidore Tahun Anggaran 2013-2017

\begin{tabular}{|c|c|c|c|c|}
\hline Tahun & $\begin{array}{c}\text { Pendapatan Asli } \\
\text { Daerah }\end{array}$ & $\begin{array}{c}\text { Total Penerimaan } \\
\text { Daerah }\end{array}$ & $\begin{array}{c}\text { Derajat } \\
\text { Desentralisasi } \\
\text { Fiskal }\end{array}$ & $\begin{array}{c}\text { Kemampuan } \\
\text { Keuangan }\end{array}$ \\
\hline 2013 & 16.351 .196 .253 & 536.164 .278 .716 & $3,04 \%$ & Sangat Baik \\
\hline 2014 & 27.672 .173 .878 & 605.901 .274 .155 & $4,56 \%$ & Sangat Baik \\
\hline 2015 & 33.695 .174 .505 & 633.364 .021 .498 & $5,32 \%$ & Sangat Baik \\
\hline 2016 & 38.730 .845 .221 & 723.191 .594 .417 & $5,35 \%$ & Sangat Baik \\
\hline 2017 & 51.238 .072 .570 & 708.623 .323 .043 & $7,23 \%$ & Sangat Baik \\
\hline \multicolumn{3}{|c|}{ Rata-rata } & $5,20 \%$ & Sangat Baik \\
\hline
\end{tabular}

Sumber : Dinas Pendapatan Daerah Kota Tidore (Data Olahan)

Rasio derajat desentralisasi fiskal digunakan untuk mengetahui dan mengukur seberapa besar kemampuan pada Dinas Pendapatan Daerah Kota Tidore dalam mengolah Pendapatan Asli Daerah (PAD). Derajat desentralisasi dihitung berdasarkan perbandingan antara jumlah PAD dengan total penerimaan daerah.

Tabel 4.2 diatas menunjukkan bagaimana pola perhitungan Rasio Derajat Desentralisasi Fiskal Kota Tidore tahun 2013 sampai dengan 2017, perhitungannya adalah dengan menggunakan Rumus, dimana Pendapatan Asli Daerah dibagikan dengan Total Penerimaan Daerah dan dikalikan dengan 100, maka hasilnya akan didapat seperti yang bisa kita lihat pada tabel diatas. Dimana pada tahun 2013 3.04\%, tahun 2014 4,56\%, tahun 2015 5,32\%, tahun 2016 5,35\% dan tahun 2017 7,23\%. Ini menunjukan kemampuan Keuangan yang ada pada Kota Tidore masih Sangat baik karena masuk dalam Skala Interval $>5,00 \%$ yaitu sangat baik, karena dalam setiap tahun mengalami peningkatan, seperti yang kita bisa lihat pada tabel diatas.

\subsubsection{Hasil Perhitungan Rasio Pertumbuhan pada Dinas Pendapatan Daerah Kota} Tidore Tahun Anggan 2013-2017

Rasio Pertumbuhan merupakan Rasio yang didapat dengan perhitungan data dengan tahun berjalan dikurangi dengan data tahun sebelumnya, maka akan didapat pertumbuhan yang ada didaerah tersebut. Melalui rasio ini kita dapat melihat dan mengukur seberapa besar pertumbuhan yang dialami oleh Pemerintah Daerah Kota Tidore pada tahun 2013 sampai dengan 2017.

Rasio Pertumbuhan merupakan Rasio yang didapat dengan perhitungan data dengan tahun berjalan dikurangi dengan data tahun sebelumnya, maka akan didapat pertumbuhan yang ada didaerah tersebut. Rasio ini dihitung mengggunakan rumus sebagai berikut:

$$
\mathrm{r}=\frac{\mathrm{Pn}-\mathrm{Po}}{\mathrm{Po}} \times 100 \%
$$


Tabel 4.3 Perhitungan Rasio Pertumbuhan Pada Dinas Pendapatan Daerah Kota Tidore Tahun Anggaran 2013-2017

\begin{tabular}{|c|c|c|c|c|c|c|}
\hline No & Keterangan & 2013 & 2014 & 2015 & 2016 & 2017 \\
\hline \multirow[t]{3}{*}{1} & PAD & $16,351,196,253$ & $27,672,173,877$ & & & \\
\hline & & & & $33,695,174,505$ & $38,730,845,221$ & $5,123,807,257$ \\
\hline & Pertumbuhan PAD & $36,84 \%$ & $69,2 \%$ & $21,76 \%$ & $14,94 \%$ & $86,77 \%$ \\
\hline \multirow[t]{2}{*}{2} & Total Penerimaan & $1,034,560,604,716$ & $1,152,457,429,155$ & 633.364 .021 .498 & 723.191 .594 .417 & 708.623 .323 .043 \\
\hline & $\begin{array}{l}\text { Pertumbuhan } \\
\text { Penerimaan }\end{array}$ & $2,98 \%$ & $11,39 \%$ & $04,72 \%$ & $15,34 \%$ & $02,44 \%$ \\
\hline \multirow[t]{2}{*}{3} & Total Belanja Rutin & 416.109 .462 .184 .00 & $\begin{array}{r}292.247 .131 .894 .0 \\
0\end{array}$ & $\begin{array}{r}347.729 .681 .314 \\
.00\end{array}$ & $\begin{array}{r}545.872 .214 .884 \\
.00\end{array}$ & $\begin{array}{r}528.921 .657 .003 \\
.00\end{array}$ \\
\hline & $\begin{array}{c}\text { Pertumbuhan Belanja } \\
\text { Rutin }\end{array}$ & & & & & \\
\hline \multirow[t]{2}{*}{4} & $\begin{array}{l}\text { Total Belanja } \\
\text { Pembangunan }\end{array}$ & 180.687 .276 .503 .00 & $\begin{array}{r}393.284 .146 .616 .0 \\
0\end{array}$ & $\begin{array}{r}379.698 .094 .668 \\
.00\end{array}$ & $\begin{array}{r}194.660 .901 .298 \\
.00\end{array}$ & $\begin{array}{r}116.671 .607 .065 \\
.00\end{array}$ \\
\hline & $\begin{array}{l}\text { Pertumbuhan Belanja } \\
\text { Pembangunan }\end{array}$ & & & & & \\
\hline
\end{tabular}

Sumber : Dinas Pendapatan Daerah Kota Tidore (Data Olahan)

Tabel 4.3 diatas menunjukkan kepada kita kondisi pertumbuhan APBD Kota Tidore dan dapat disimpulkan bahwa APBD pada tahun 2013 sampai 2017 menunjukan pertumbuhan yang positif meskipun relatif sangat rendah. pertumbuhan di daerah Kota Tidore mengalami fluktuasi Hal ini menunjukan bahwa Pemerintah Daerah Kota Tidore tidak terlalu memberikan perhatiannya terhadap pembangunan daerahnya dan kesejahteraan masyarakatnya.

\subsection{Pembahasan}

4.2.1 Penilaian Kemampuan Keuangan daerah Pada Dinas Pendapatan Daerah Kota Tidore berdasarkan Rasio kemandirian Tahun Anggaran 2013-2014.

Hasil Penilaian kemampuan keuangan berdasarkan Rasio Kemandirian menunjukan bahwa pendaptan asli daerah dibagi dengan Total Pendapatan Dari Pihak Ekstern dan dikalikan dengan 100, maka hasilnya akan didapat, dimana Rasio kemandirian pada tahun 2007 2,17\%, tahun 2008 2,12\%, tahun 2009 2,41\%, tahun 2010 2,30\% tahun 2011 2,76\%, tahun 2012, 3,47\%, tahun 2013, 3,61\%, tahun 2014, 4,79\% dan tahun 2015, 5,65\% ini menunjukan pola hubungan Rasio Kemandirian yang ada di Kota Tidore tahun 2013 sampai dengan 2017 adalah instruktif (sangat baik) adalah instruktif. Sedangkan intrusktif bila dilihat dari rasio kemandirian adalah, suatu posisi pola hubungan dan tingkat kemampuan daerah yang sangat baik yaitu $>50,00 \%$.

\subsubsection{Penilaian Kemampuan Pada Dinas Pendapatan Daerah Kota Tidore} Berdasarkan Rasio Derajat Desentralisasi Fiskal Tahun Anggaran 2013-2017.

Hasil penilaian kemampuan keuangan daerah Kota Tidore berdasarkan rasio derajat desentralisasi fiskal, yaitu dengan menggunakan Rumus, dimana Pendapatan Asli Daerah dibagikan dengan Total Penerimaan Daerah dan dikalikan dengan 100, Dimana pada tahun tahun 2013 3.04\%, tahun 2014 4,56\%, tahun 2015 5,32\%, tahun 2016 5,35\% dan tahun 2017 7,23\%. Ini menunjukan kemampuan Keuangan yang ada pada Kota Tidore sangat baik karena masuk dalam Skala Interval $>5,00 \%$ yaitu sangat baik, meskipun demikian hal ini menujukan penigkatan pendapatan asli daerah terhadap total penerimaan daerah Kota Tidore tahun 2013-2017 selalu mengalami peningkatan. Implikasi dari masalah ini adalah agar PAD bisa lebih meningkat, maka total penerimaan yang ada di Kota Tidore bisa lebih tinggi, dan tingkat kemampuan keuangan daerah lebih stabil lagi pada tahun-tahun yang akan datang.

\subsubsection{Penilaian Kemampuan pada Dinas Pendapatan Daerah Kota Tidore Berdasarkan Rasio Pertumbuhan Tahun Anggaran 2013-2017}

Hasil penilaian kemapuan keuangan daerah berdasarkan rasio pertumbuhan yaitu, APBD pada tahun 2013 sampai 2017 menunjukan pertumbuhan yang positif meskipun relatif 
sangat rendah. pertumbuhan di daerah Kota Tidore mengalami fluktuasi Hal ini menunjukan bahwa Pemerintah Daerah Kota Tidore tidak terlalu memberikan perhatiannya terhadap pembangunan daerahnya dan kesejahteraan masyarakatnya.

Implikasi dari masalah ini yaitu kurangnya perhatian pemerintah daerah kota tidore terhadap daerah-daerah dan masyarakatnya, sehingga lemahnya pertumbuhan yang ada didaerah kota tidore, sebaiknya pemerintah kota tidore, lebih lagi memperhatikan pembangunan-pembangunan yang ada disetiap daerahnya masing-masing, agar pertumbuhan pembangunan bisa terus meningkat dengan lebih baik lagi, dan juga bisa lebih meningkatkan Pendapatan Asli Daerah yang ada di Kota Tidore sehingga kemampuan keuangan daerah bisa lebih masksimal dan lebih stabil.

\subsubsection{Hasil Penilaian Kemampuan pada Dinas Pendapatan Daerah Kota Tidore Tahun Anggaran 2013-2017.}

Hasil analisis menunjukan bahwa kemampuan PAD dalam membiayai pelaksaan pembangunan daerah sudah sangat baik dilihat dari rata-rata Rasio kemandirian dari tahun 2013-2017 >50.00\% ini mennunjukan kemampuan keuangan instruktif (sangat baik), dilihat dari rata-rata Rasio Derajat Desentralisasi Fiskal tahun 2013-2017 yaitu, 5,20\% ini menunjukan kemampuan keuangan daerah Kota Tidore sudah lumayan sangat baik, dan Jika dilihat dari rata-rata Rasio Pertumbuhan tahun 2013-2017, menunjukan pertumbuhan yang positif meskipun relatif rendah. Seperti yang kita lihat dari hasil pembahasan penelitian ini menunjukan bahwa rata-rata dari keseluruhan Rasio yang diteliti masih sangat rendah jika dilihat tingkat kemampuan keuangan daerahnya. Dimana pola hubungan $>50,00 \%$ (sangat tinggi), skala interval $40.02 \%$ s/d $60.00 \%$ (cukup), dan pertumbuhan keungan daerah yang masih rendah.

Hasil analisis dalam penelitian ini sama dengan hasil penelitian yang dilakukan oleh Rumetor (2013) diamana dalam penelitiannya tentang "analisis tingkat kemampuan keuangan daerah d ikota manado pasca otonomi daerah dikota manado", diamana kemampuan keuangan daerah yang ada dikota manado masih sangat rendah. Dilihat dari Rasio kemandirian, rasio Derajat Desentralisasi Fiskal dan Rasio Pertumbuhan yang ada di Kota Manado Masih Rendah. Begitu juga dengan hasil penelitian yang diteliti oleh wibowo (2001) dan Meri Imelda yusuf (2013) Masih Rendah.

Dari penelitian yang dilakukan dengan menggunakan Rasio kemandirian, Rasio Derajat Desentralisasi Fiskal dan Rasio Pertumbuhan daerah dapat disimpulkan bahwa pemerintah Kota Tidore pasca otonomi daerah sudah mampu mengelolah dan mengoptimalkan Pendapatan Asli Daerah (PAD), karena kemampuan keuangan yang instruktif (sangat tinggi), masih kurang dan masih bergantung pada penerimaan Pemerintah Pusat yang ada di Kota Tidore.

\section{KESIMPULAN DAN SARAN}

\subsection{Kesimpulan}

1) Kemampuan Keuangan Kota Tidore dilihat dari Rasio Kemandirian tahun 2013-2017 termasuk dalam pola hubungan Instruktif (sangat tinggi), ini menunjukan bahwa kemamapuan Pemerintah Kota Tidore dalam memenuhi kebutuhan dalam penyelenggaraan tugas dan kewajiban, pembangunan serta pelayanan sosial masyarakat sudah tergolong sangat tinggi dan sangat baik.. Ini berarti Pemerintah kota Tidore sudah mampu meningkatkan kemampuan keuangannya.

2) Perhitungan rasio Derajat Desentralisasi Fiskal menunjukkan bahwa kemampuan keuangan daerah yang ada di Kota Tidore dari tahun 2013-2016 dilihat dari rata-rata atau keseluruhan tergolong dalam skala interval $40.02 \% \mathrm{~s} / \mathrm{d} 60.00 \%$, yang mana menunjukan kemampuan Keuangan yang ada pada Kota Tidore masih mengalami kestabilan dan mengalami peningkatan dari tahun ke tahun. 
3) Berdasarkan Rasio Pertumbuhan Kota Tidore, dilihat dari PAD sangat tinggi, 2013 sampai 2017 menunjukan pertumbuhan yang positif. Pertumbuhan di daerah Kota Tidore mengalami Kestabilan Hal ini menunjukan bahwa Pemerintah Daerah Kota Tidore memberikan perhatiannya terhadap pembangunan daerah dan kesejahteraan masyarakatnya.

\subsection{Saran}

1. Meningkatkan terus kinerja pengelolaan terhadap realisasi APBD, agar Kota Tidore mampu menjadi kota yang mandiri tanpa ketergantungan yang besar terhadap bantuan dana dari pemerintah pusat maupun provinsi.

2. Meningkatkan lagi Pertumbuhan yang ada di Kota Tidore agar pada tahun berikutnya Perumbuhan yang ada di Kota Tidore bisa lebih ditingkatkan lagi.

\section{DAFTAR PUSTAKA}

Abdul Halim dkk, 2012 . Akuntansi Sektor Publik Akuntansi Keuangan Daerah. Edisi 4. Penerbit Salemba Empat. Jakarta

Adisubrata, W. Surya. 2003. Perkembangan Otonomi Daerah di Indonesia (SejakProklamasi Sampai Awal Reformasi) 1. Semarang: CV. Aneka Ilmu

Halim, Abdul dan Damayanti, T. 2007. Pengelolaan Keuangan Daerah. Yogyakarta: UPP STIM YKPN.

Halim, Abdul. 2004. Manajemen Keuangan Daerah (Edisi Revisi). Yogyakarta: UPP AMP YKPN.

IhyaulUlum, 2009. Audit Sektor Publik: SuatuPengantar. Jakarta. Penerbit PT BumiAksara

Mamesa, D.J. 1995. Sistem Administrasi Keuangan Daerah. Jakarta: Pustaka Utama.

Peraturan Pemerintah Nomor 58 tahun 2005 tentang Pengelolaan Keuangan Daerah .9 Desember 2005. Lembaran Negara Republik Indonesia tahun 2005Nomor 140.

Sugiono. 2016. Memahami Penelitian Kualitatif. Alfabeta. Bandung.

Undang-undang Republik Indonesia Nomor 32 Tahun 2004 tentang Pemerintah Daerah. Lembaran Negara Republik Indonesia Tahun 2004 Nomor 4437. Jakarta.

Undang-undang Republik Indonesia Nomor 58 Tahun 2005 tentang Pengelolaan Keuangan Daerah. 9 Desemeber 2005. Lembaga Negara Republik Indonesia Tahun 2005 Nomor 140. Jakarta.

Widodo, Joko.2001 Good Governance: Telah dari Dimensi: Akuntabilitas dan Kontrol Birokrasi pada Era Desentralisasi dan Otonomi Daerah. Insan Cedekia. Surabaya.

Yulianti,2001. Analisis Kemampuan Keuangan Daerah dalam Menghadapi Otonomi Daerah. Bunga Rampai Manajemen Keuangan Daerah. 